\title{
PEMIKIRAN TAFSIR SHAYKH MUHAMMAD ABDUH
}

\author{
Ahmad Nabil Amir \\ International Institute of Islamic Thought and Civilization (ISTAC-IIUM) Kuala Lumpur \\ nabiller2002@yahoo.co.uk
}

Diterima 15 April 2021 | Direview 20 Mei 2021 | Diterbitkan 30 Juni 2021

\begin{abstract}
This paper analyzes the method of tafsir al-ilmi (scientific) outlined in the book Tafsir al-Qur'än al-Hakim or Tafsir al-Manär by Shaykh Muhammad Abduh (1849-1905) and Rashi d Ridā (1865-1935). This work presents an effective manhaj tafsir akliah that emphasizes rational and scientific understanding of the verses of the Qur'an. This paper will discuss the background of the interpreters, the views and scientific thoughts raised in their works, the idealism of the reforms devised and the manhaj highlighted in the interpretation of the verses related to ittijäh 'ilm (scientific). This book. formulates a precise scientific manhaj and expresses a high appreciation for the efforts of ijtihad and inference. This study will map the ideas and analyze the power of the methods sketched out in triggering the enlightenment of the mind, science, anthropology, sociology, and culture, and their influence on the works of tafsir in the modern century.
\end{abstract}

Keywords: Muhammad Abduh, Tafsir al-Manar, Tafsir al-Tlm.

Abstrak

Kertas ini menganalisis metode tafsìr al-ïlmì (saintifik) yang digariskan dalam kitab Tafsìr al-Qur'än al-Hakim atau Tafsï alManār oleh Shaykh Muhammad Abdub (1849-1905) dan Rashid Rid̄a (1865-1935). Karya ini mengemukakan manhaj tafsir akliah yang mempan yang menekankan kefahaman rasional dan saintifik terhadap ayat-ayat al-Qur'an. Tulisan ini akan membincangkan latar belakang pentafsir, pandangan dan pemikiran saintifik yang diangkat dalam karya mereka, idealisme pembaharuan yang digagaskan dan manhaj yang diketengabkan dalam tafsiran ayat-ayat yang berkait dengan ittijäh ilm (saintifike.). Kitab ini merumuskan manhaj saintifik yang jitu dan menzabirkan apresiasi yang tinggi terbadap upaya ijtibad dan istinbat. Kajian ini akan memetakan ide dan menganalisis kekuatan metode yang dilakarkan dalam mencetus pencerahan akal, sains, antropologi, sosiologi, dan budaya, dan pengarubnya terbadap karya-karya tafsir di abad moden.

Kata Kunci: Muhammad Abduh, Tafsir al-Manar, Tafsir al-'Tlm.

\section{Pendahuluan}

Kemunculan ide tentang sains dan teknologi (al-'ulüm wa'l-taqnìy yàt) mula dicetuskan dari gagasan pembaharuan dan tradisi akliah yang digerakkan oleh pemikir dan filosof Barat yang radikal dalam usaha menolak cengkaman gereja ke atas kebebasan. Usaha yang keras ini telah menyumbang kepada pencerahan dan kebangkitan sains pada akhir kurun ke 17 yang mengilhamkan penemuan ide dan pemikiran yang kritikal dalam era renaisans. Ia berhasil mempengaruhi dan mengesani aliran dan tradisi pemikiran Islam moden, yang menerobos dalam kajian falsafah, sains, kalam dan tafsir dan telah melantarkan asas yang penting terhadap kebangkitan Tafsir al-Tlm dan gagasan saintifiknya. Perkembangan sains moden telah mencetuskan pembaharuan dalam pandangan dunia dan welstanchauung Islam yang infinit. Penemuan yang penting ini memberi pengaruh yang jelas terhadap corak dan pandangan saintifik dan upaya takwil seperti dihuraikan oleh Muzaffar Iqbal dalam karyanya The Making of Islamic Science: "with the emergence of the new discourse on Islam and science during the post-seventeenth century era, when books started to appear with the verse from the Qur'an purporting to confirm scientific theories. In the end, a new kind of Qur'anic exegesis appeared in full bloom: al-Tafsir al-Tlm, the scientific tafsir" (dengan kemunculan wacana baru tentang Islam dan sains dalam pasca-kurun ketujuh belas, ketika buku-buku mula memaparkan ayat dari al-Qur'an bertujuan mengesahkan teori sains. Pada akhirnya, suatu bentuk tafsiran al-Qur'an yang baru mekar: al-Tafsir al-Tlm, tafsir saintifik). ${ }^{1}$

Antara karya terbaik yang mengetengahkan manhaj saintifik ini adalah kitab Tafsir alManär yang mengemukakan kefahaman teks yang kritis tentang idealisme sains. Garapannya yang luas terhadap tema rasional dan saintifik dan keberkesanannya dalam mempertahan pilarpilar sains dalam al-Qur'an menjadikannya kitab yang ideal untuk diangkat sebagai alternatif

${ }^{1}$ Muzaffar Iqbal. The Making of Islamic Science. (Westport, Connecticut: Greenwood Press, 2007), 179 
dalam kajian tafsir. Penulisan tafsir ini juga digarisbawahi oleh perjuangan menuntut tajdid dan keunggulan akal dan daya nalar dan keperluan ijtihad di dunia Islam yang dipelopori dan digerakkan oleh kedua penafsirnya di permulaan abad kedua puluh.

\section{Perkembangan Tafsir al-'IIm}

Tafsir al-Tlm ialah tafsir yang menyodorkan pandangan saintifik dan rasional dalam tafsir. Ia menekankan manhaj empirik dan saintifik dalam menangani teks dan mensejajarkan penemuan sains dengan ayat al-Qur'an dan menyerlahkan ketinggian dan keabsahannya dalam konteks moden. Ide dan manhaj tafsir yang signifikan ini telah digariskan oleh pelopor mazhab rasional dan akliah moden (madrasah al-'aqliyah wa al-hadäthah) yang memperjuangkan kebangkitan sains di dunia Islam seperti Sir Sayyid Ahmad Khan (w. 1898), Sayid Jamal alDin Afghani, dan Shaykh Muhammad Abduh. Secara asasnya, fikrah tentang tafsir al-ilm ini telah dilakar pada kurun ke $5 \mathrm{H}$ dalam penulisan-penulisan Islam klasik. Kerangka besar dan ide fundamental tentang Tafsir al- Tlm telah dibahas oleh Imam al-Ghazali (w. 505 H/1111 M) dalam kitabnya Ihyà ' Ulüm al-Din, yang berhujah bahawa al-Qur'an mengandungi ilmu umat yang terdahulu dan terkemudian (al-awwalin wa'l-äkhirin), dan merangkumi seluruh pengetahuan. Menurutnya, "semua yang musykil kefahamannya kepada fikiran dan berbentur dengan pandangan nazari dan akal maka di dalam al-Qur'ān terdapat simbol dan dalil yang menunjukkannya yang khusus difahami oleh kalangan yang arif dalam funün nya, kecuali apa yang perlu kepada penjelasan dan huraian maknanya, dengan cara pertengahan tidak jauh melampau dan ekstrim." 2

Pandangan saintifik yang mendasar ini turut dipertahankan oleh Imam Fakhr al-Din alRazi dalam tafsirnya Mafatih al-Ghayb: "Qur’ān adalah pokok dan asal sekalian ilmu baik hal dunia maupun akhirat. Baik ahli nahu, saraf, balaghah, fiqih, usul fiqih, usuluddin, doktor, falak dan lain-lain semuanya mengambil dari Qur'ān.” (Abdul Halim Hasan, Zainal Arifin Abbas, Abdul Rahim Haitami, 1956, 1/90). Argumen ini turut diperkuatkan oleh Ibn Abi alFaḍl al-Mursī yang berhujah bahawa asas pertukangan telah digariskan dalam al-Qur'ān, dan menampilkan ayat yang dapat memperkuat argumennya. Ide ini turut diungkap oleh Imam al-

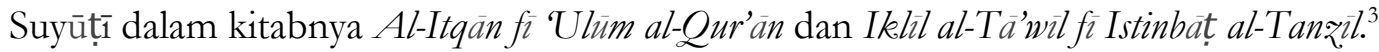

Perbincangan tentang kerangka tafsir al-ilm ini telah dibahas oleh ramai ulama tafsir seperti Muhammad 'Iffat al-Sharqāwī dalam Ittijāhāt al-Tafsì fì Mișr fil-'Așr al-Hadīth dan Dr. Muhammad Husayn al-Dhahabi dalam kitabnya, Tafsir wa'l-Mufassirün yang mengetengahkan fasal yang mendetil tentang mazhab tafsir al-ilm. Muzaffar Iqbal dalam The Making of Islamic Science turut memberikan analisis yang mendalam terhadap prinsip dan karakteristik asas tafsir al-ílm. Menurut Muzaffar, tradisi saintifik telah berakar di dalam Qur'an dan tidak perlu mencarinya semula untuk mengabsahkannya, "thus, because the Islamic scientific tradition was naturally rooted in the Qur'anic worldview and because it shared a common universe of discourse within the divine revelation, there was never any need to read back into the "Word of God" any scientific discovery or explanation of the "Work of God" (justeru, kerana tradisi sains Islam secara naturnya berakar dari pandangan al-Qur'an dan kerana ia berkongsi alam diskursi yang sama dengan wahyu Ilahi, maka tidak wujud sebarang keperluan untuk membaca semula pada "Kalam Ilahi" sebarang penemuan sains atau pentafsiran tentang "kerja Tuhan"). Menurutnya tradisi saintifik hanya berkembang pada kurun ke 19-20 M yang digerakkan dengan meluas kerana pengaruh saintifik Eropah dan dikembangkan oleh mufassir dan pemikir Islam moden, dan setelah umat Islam terancam oleh serangan imperialis, "it was only after a number of reformers had written scientific exegesis of the Qur'an, al-tafsir al-ilmi, with the sole aim of finding sanctity for the modern science in the Qur'an in order to encourage Muslims to acquire it, that the discourse gained popularity among some scientists and religious scholars" (hanya setelah sejumlah reformis menulis tafsir saintifik terhadap al-Qur'an,

${ }^{2}$ Abu Hamid Muhammad Al-Ghazali, Ihyà' 'Ulüm al-Din, juz 3. (Beirut: Dar al-Ma'rifa, t.t), 289.

3Ismail Abdullah, Sayuti Abdul Manas. "Manhaj al-Shaykh Țanțāwī Jawharī fì Tafsīrihi "al-Jawāhir fì Tafsìr al-Qur'ān al-Karim," Journal of Islam in Asia, 2, 2011, 33-52. 
al-tafsir al-ilmi, dengan tujuan untuk mencari nilai kudus bagi sains moden dalam al-Qur'an bagi menggalakkan umat Islam mempelajarinya, maka wacana tersebut meraih populariti di kalangan saintis dan ahli agama) ${ }^{4}$

Perkembangan awal dan moden dari aliran tafsir al-ilm di Mesir tercetus pada tahun 1880, dengan kitab Kashf al-Asrär al-Nüräniyyah al-Qur'āniyyah, fì mā Yata'allaq bi al-Ajrām alSamawiyyah, wa'l-Ardiyyah, wa'l-Hayawànät, wa'l-Nabätät, wa'l-Jawähir al-Ma'daniyyah, [The unveiling of the luminous secrets of the Qur'an in which are discussed celestial bodies, the earth, animals, plants and minerals] oleh Dr. Muhammad b. Ahmad al-Iskandarani (w. 1306 H), yang mencetuskan momentum yang besar terhadap perkembangan tafsir al-ilm selepasnya. Ia melantarkan tentang dalil empirik dalam al-Qur'an dan kehujahan saintifiknya dan membincangkan tentang perkembangan ide sains yang meluas di Eropa. Idealisme saintifik ini dilakarkan dengan terperinci dalam muqaddimah tafsirnya: "dan aku sejak berlabuh tirai masa kanak-kanak dan meningkat matang dan dewasa, merupakan antara yang tekun mempelajari ilmu kedoktoran sepanjang waktu, dan gigih menekuninya dalam perkisaran tahun dan masa, setelah itu aku menetap di Damsyik Syria menjalankan ikhtiar untuk merawat ahlinya yang wibawa dan terkemuka, sehingga aku mengunjungi satu majlis pertemuan pada tahun $1290 \mathrm{H}$ yang turut dihadiri doktor-doktor Kristen, lalu mereka mula membahas tentang kaedah pembentukan logam, dan adakah ia diisyaratkan dalam kitab Taurat dan Injil atau tidak? Malangnya mereka tidak berhasil menemui sesuatu, baik secara nyata atau tersirat, kemudian mereka mengarahkan pertanyaan kepadaku tentang al-Qur'an al-Karim adakah diisyaratkan di dalamnya, lantas aku cuba menjawab dengan memperhalusi dan mendalami kefahaman dan perbincangannya, setakat kemampuan dan keupayaanku, dan aku menelusuri perkataan para ulama, dan aku khususkan pencariannya dalam kitab-kitab tafsir dan kedoktoran, dan diperkuatkan dengan ijtihad." ${ }^{5}$

Al-Iskandarani turut menghasilkan karya saintifik yang ideal yang menzahirkan kefahaman sains tabii yang unik dalam kitab Tibyān al-Asrär al-Rabbäniyya fi'l-Nabät wa'lMa'ädin wa'l-Khawaș al-Haywaniyya (The Demonstration of Divine Secrets in the Vegetation and Minerals and in the Characteristics of Animals). Ia mempertahankan penemuan sains Eropa dan pengemukaan teorinya yang spesifik, yang diketengahkan dengan hasrat mengerahkan kesedaran umat Islam dalam penerokan sains moden. Karyanya telah memberikan dampak yang luar biasa terhadap kebangkitan aliran tafsir al-ilm setelahnya, dengan karya-karya tafsir yang lahir dalam arus perkembangan pemikiran saintifik di Mesir seperti Tafsir al-Manār, al-Jawāhir, dan al-MușhafalMufassar.

\section{Tafsīr al-Manār dan Manhaj al-'Ilm}

Tafsir al-Manār adalah sebuah tafsir moden yang dikarang oleh Sayid Muhammad Rashid Rida (1865-1935). Ia dihasilkan dari tafsir al-Qur'an yang disampaikan oleh Shaykh Muhammad Abduh (1849-1905) di Jāmi‘ al-Azhar pada 1900/01 dan diterbitkan dalam dua belas jilid, yang dikenal sebagai Tafsir Muhammad 'Abduh. Ide untuk menyusun tafsir al-Qur'an ini disarankan oleh Rida pada Ramadan 1315 H/1897 M kepada Abduh untuk menulis tafsir seperti yang dikerjakannya dalam al-'Urwa al-Wuthqä di Paris, dan kerana "Abduh telah biasa menyampaikan kuliah tafsir al-Qur'an di beberapa tempat di Mesir dan di tempat-tempat lain."”. Kuliah tafsir ini disampaikan sejak awal Muharram 1317 H/1899 M hingga pertengahan Muharram $1323 \mathrm{H} / 1905 \mathrm{M}$ yang merangkumi lima surah, dari al-Fatihah hingga surah al-Nisa' ayat 125 (ayat "dan milik Allah segala yang ada di langit dan di bumi, dan Allah Maha Meliputi atas tiap-tiap sesuatu”). Pendekatan Abduh dalam tafsirnya adalah berasaskan metode saintifik dan rasional, yang menekankan fungsi al-Qur'an sebagai bidayah (petunjuk)

${ }^{4}$ Muzaffar Iqbal. The Making of Islamic Science. Westport (Connecticut: Greenwood Press, 2007), 280.

${ }^{5} \mathrm{Al}-\mathrm{Rūm} \overline{1}$, Fahd 'Abd al-Raḥman, Ittijāhāt al-Tafsìr fì al-Qarn al-Rābi' 'Ashar. (Beirut: Mu'assasah al-Risālah, 1986), 679.

${ }^{6}$ Mustaffa Abdullah. "Sejarah Penulisan Tafsir al-Manar Karya Sayyid Muhammad Rasyid Rida," Jurnal al-Bayan vol. 3 (2005), 55-64. 
kepada umat manusia yang menggariskan penyelesaian kepada semua kemusykilan yang dihadapinya.

Tujuan ini, menarik kekaguman ahli dan mufakkir besar, seperti diungkap oleh Mahmud Yunus dalam tafsirnya Tafsir Quran Karim: "dalam tafsir ini yang lebih dipentingkan ialah menerangkan dan menjelaskan petunjuk-petunjuk yang termaktub dalam al-Qur'an, untuk diamalkan oleh kaum Muslimin khususnya dan umat manusia umumnya, sebagai petunjuk universal. Karena petunjuk itulah tujuan yang utama dalam kitab suci al-Qur'an.”’

Tafsirnya dilakar, "dengan mengambil kira keperluan masyarakat Islam pada waktu itu dan tidak terikat dengan tafsiran-tafsiran yang sudah ada, serta mengetengahkan isu-isu yang berkaitan dengan asas keistimewaan Islam yang kurang dibincangkan oleh ulama sebelumnya." "Tafsir yang dikerjakan Abduh dilanjutkan oleh Rida dengan penafsiran surah al-Nisa' ayat 126 hingga surah Yusuf (as) ayat 101, dan tafsirnya disempurnakan oleh Shaykh Muḥammad Bahjat al-Bayțār yang menuntaskannya hingga ayat 111 yang dicetak berasingan dengan judul Tafsì Sayyid Muhammad Rashid Rid̄à.

Penulisan tafsir ini dilatari oleh fikrah pembaharuan dan nahdah yang dikobarkan oleh al-Afghani, Abduh dan Rida, yang berusaha meniupkan aspirasi moden dalam pemikiran tafsir seperti dijelaskan oleh M. Quraish Shihab dalam bukunya Rationalitas Al-Qur'an: Studi Kritis atas Tafsir al-Manar: "kitab tafsir ini pada dasarnya merupakan karya tokoh Muslim terkemuka, Sayyid Jamaluddin al-Afghani, Syaikh Muhammad Abduh, Sayyid Muhammad Rashid Ridha. Al-Afghani menebar gagasan pembaruan masyarakat Muslim, yang dicerna, diolah dan kemudian disampaikan melalui penafsiran ayat-ayat al-Qur'an oleh Muhammad Abduh. Rasyid Ridha menuliskan semua yang disampaikan oleh sahabat dan gurunya itu dalam bentuk ringkasan dan penjelasan." Tafsir al-Manār ini mempunyai ciri yang tersendiri dengan nilainilai kemandirian, dalam mengaitkan ajaran-ajaran al-Qur'an dengan masyarakat dan kehidupan, dan menegaskan Islam sebagai agama universal dan abadi, "yang selalu sesuai dengan kebutuhan manusia di segala waktu dan tempat, dan menyelaraskan ajaran al-Qur'an dengan perkembangan ilmu pengetahuan saat itu." Abduh menekankan bahawa Al-Qur'an diturunkan sebagai petunjuk yang menangani segenap urusan keagamaan dan keduniaan, dan risalahnya dapat difahami dan ditangani untuk seluruh umat, seperti dipaparkan oleh Quraish Shihab: "dan ini sejalan dengan pandangan 'Abduh yang menyatakan bahawa al-Qur'an berdialog dengan semua manusia sejak turunnya hingga akhir zaman, sehingga dia berlaku umum untuk setiap masa dan generasi. Karena itu, menjadi kewajipan setiap orang untuk memahami ayat-ayat al-Qur'an sesuai dengan kemampuan masing-masing."

Sejak awal penerbitannya dalam majalah al-Manār, ia telah menggerakkan faham pembaharuan yang substantif dan menzahirkan pengaruh tajdid yang berkesan di Mesir, yang berhasil memperkuat ideologi dan pengaruh Abduh yang meluas dan melegitimasi pemikirannya, "karena itu, tafsir al-Qur'an karya Rida ini tidak hanya menafsirkan ayat-ayat al-Qur'an, tapi juga menjadi media dan corong pembaruan yang digulirkan oleh gurunya, Muhammad Abduh.”. Idealisme pembaharuan ini diperjuangkan oleh Rida dengan kental, "yang tidak pernah mengenal lelah dalam memublikasikan dan menyebarluaskan pemikiranpemikiran Abduh ke seluruh dunia Islam melalui majalah al-Manar, Tafsì al-Manär dan karyakaryanya yang lain." ${ }^{10}$ Menurut 'Abdullāh Maḥmūd Syaḥātah dalam kajiannya tentang manhaj dan fikrah moden yang digariskan oleh Abduh dalam tafsirnya, "seandainya Rida tidak pernah

${ }^{7}$ H. Mahmud Yunus. Tafsir Quran Karim. (Kuala Lumpur: Pustaka al-Azhar, 1987), v.

${ }^{8}$ Muhammad al-Fadi. Al-Tafsir wa Rijäluh. (Kaherah: Majma“ al-Buhuth al-Islamiyyah, 1970), 173; Mustaffa Abdullah. "Sejarah Penulisan Tafsir al-Manar Karya Sayyid Muhammad Rasyid Rida," Jurnal al-Bayan vol. 3 (2005), 59.

${ }^{9}$ M. Quraish Shihab. Rasionalitas Al-Qur'an: Studi Kritis atas Tafsir al-Manar (Ciputat: Lentera Hati, 2006), 5

${ }^{10}$ A. Athaillah. Rasyid Ridha: Konsep Teologi Rasional dalam Tafsir al-Manar (Jakarta: Erlangga, 2006). 
memublikasikan gagasan pembaruan 'Abduh, kita tidak akan dapat mengenal gagasannya yang brilian, khususnya di bidang tafsir.""11

Metode yang digariskan dalam Tafsìr al-Manār adalah bercorak al-adabi al-ijtimā'r (sastera dan budaya), yang "menayangkan ketentuan alam yang besar dan aturan sosial, menangani kemusykilan umat Islam secara khusus, dan kemusykilan umat manusia yang umum, dengan apa yang ditunjukkan oleh al-Qur'an, dari bimbingan dan pengajarannya, dan menghimpun antara kebaikan dunia dan akhirat, serta mendamaikan antara al-Qur'an dan apa yang diithbatkan sains dan teori ilmiah yang sahih." 12

Tafsirnya menggarap manhaj penafsiran moden dan kontemporer dan menekankan prinsip dan idealisme saintifik, dan mempertahankan manhaj al-ma'thür dan ma'qül dalam penafsiran, seperti dilakarkan dalam muqaddimahnya: "Ini adalah satu-satunya tafsir yang mencantumkan tafsir al-ma'thür yang sahih dan tafsir al-ma'qül (aqliah) yang șarḥ (jelas), yang menjelaskan hukum syarak, dan sunan (ketentuan) Allah pada insan, dan kenyataan al-Qur'an sebagai bidàyah (petunjuk) untuk manusia di setiap tempat dan masa, dan menimbangkan antara hidayahnya dengan kondisi manusia pada waktu ini. Dan sesungguhnya mereka telah membelakangkannya, dan keadaan kaum salaf (terdahulu) daripada mereka yang mendakap talinya dengan erat, dengan meraikan kemudahan pada ta'birnya (ungkapan), dan menjauhi perbahasan yang berkait dengan peristilahan sains dan seni, dengan cara yang difahami oleh umum, dan tidak dapat disingkirkan olehnya kaum yang khusus. Demikian inilah haluan yang diikuti olehnya ketika menyampaikan durüsnya (pengajian) di (Jämi') al-Azhar oleh Hakim alIslām al-Ustādh al-Imām al-Shaykh Muḥammad "Abduh"13.

Menurut M. Quraish Shihab dalam pengantarnya kepada terjemahan kitab Tafsir Juz 'Amma karya Abduh, manhaj yang dilakarkan Abduh adalah berpijak kepada pandangan akliah yang jelas, meraikan kondisi sosial dan landasan asas bahasa Arab, seperti dirumuskannya: "Abduh menjadikan akal dan kondisi sosial, bersama dengan bahasa Arab sebagai alat yang amat pokok dalam memahami al-Qur'an." "14 Menurutnya, 'Abduh menekankan bahawa tafsir harus dapat dimengerti dengan mudah sehingga dapat menjadi budā (petunjuk) bagi meraih kebahagiaan duniawi dan ukhrawi, sesuai dengan fungsi diturunkannya al-Qu'ran. Pertikaian pendapat dan ikhtilaf yang dipaparkan hanya menjauhkannya dari tujuannya, "Allah tidak akan menanyakan kepada kita tentang pendapat-pendapat itu, dan masyarakat pun tidak membutuhkannya." Dalam tafsir yang diusahakannya "tidak ditemukan perbedaan-perbedaan pendapat, juga uraiannya dapat dengan mudah difahami oleh pembacanya."

Quraish turut membandingkan corak pemikiran Abduh dalam Tafsir Juг 'Amma (tafsirnya yang ringkas yang dikarang di Maghribi, pada tahun $1321 \mathrm{H}$, sebagai rujukan dan pegangan guru mengaji) dengan Tafsìr al-Manār, di mana sementara Tafsìr Juz 'Amma mempertahankan idealisme salaf, ini "berbeda dengan Tafsir al-Manār, yang cirinya sangat rasional sehingga dinilai oleh sementara pakar sebagai uraian yang mempersempit sekecil mungkin wilayah gaib dan suprarasional karena segala sesuatu diupayakan oleh Abduh dalam Tafsir al-Manar itu untuk dirasionalkan." 15 Dalam Tafsir al-Manär Abduh digambarkan sebagai seorang mufassir yang memberi penilaian yang tinggi kepada daya nalar yang melebihi penganut aliran mu'tazilah, kerana tolok ukur yang digunakannya untuk penerimaan atau penolakan riwayat, semata-mata adalah pertimbangan rasionalnya.

11‘Abdullāh Maḥmūd Syaḥātah. Manhaj al-Imām Muhammad 'Abduh fì Tafsìr al-Qur'àn al-Karìm. (Kaherah: al-Majlis al-A`lā li Ri`āyah al-Funūn wa al-Adab wa al-'Ulūm al-Islāmiyyah, t.t)

${ }^{12}$ Muḥammad Husayn al-Dhahabī. Al-Tafsìr wa'l-Mufassirūn. (Cairo: Maktabah Wahbah, 2003), 588-9.

${ }^{13}$ Ridā, Rashīd, Tafsìr al-Qur'àn al-Hakìm al-mushtahar bi ism Tafsìr al-Manār. Cet. 2. (Kaherah: Dar al-Manar, 1947), 1.

${ }^{14}$ Muhammad Abduh. Tafsir Juг 'Amma, terj. Muhammad Baqir. Pengantar oleh M. Quraish Shihab. (Jakarta: Penerbit Mizan, 1998).

${ }^{15}$ Muhammad Abduh. Tafsir Juz 'Amma, terj. Muhammad Baqir. Pengantar oleh M. Quraish Shihab. (Jakarta: Penerbit Mizan, 1998), x. 
Patokan, atau prinsip yang dianut Abduh dalam uraiannya terhadap ayat-ayat al-Qur'an, dirumuskan dengan tuntas oleh para pengkajinya seperti berikut: (1) memandang setiap surah sebagai satu kesatuan ayat-ayat yang serasi (2) menjadikan al-Qur'an sebagai sumber akidah dan hukum, bukan melegitimasi pandangan mazhab melalui al-Qur'an (3) al-Qur'an berdialog dengan semua generasi (4) tidak merinci ayat-ayat yang sifatnya mubham atau sepintas lalu (5) sangat kritis terhadap riwayat-riwayat baik hadith Nabi (saw), maupun pendapat para sahabat (rad) Baginda (saw) dan tabi'in. ${ }^{16}$ (Muhammad Abduh, 1998, viii) Tafsirnya melantarkan asas saintifik yang mencerahkan fikiran-fikiran masyarakat, dan tuntas membela ajaran-ajaran Islam yang disalahfahami barat. Menurut Quraish Shihab, dua fokus utama dalam pemikiran Abduh, adalah "membebaskan umat dari taqlid dengan berupaya memahami agama langsung dari sumbernya - al-Qur'an dan sunnah - sebagaimana dipahami oleh salaful ummah, dan memperbaiki gaya bahasa Arab yang sangat bertele-tele yang dipenuhi oleh kaidah-kaidah kebahasaan yang sulit dimengerti, dan kedua fokus tersebut ditemukan dengan sangat jelas dalam karya-karya Abduh di bidang tafsir."

Manhaj saintifik yang digariskan Abduh ini dilanjutkan oleh Rida, setelah kewafatannya, dengan memberi inayah khusus kepada hidayah al-Qur'an, dengan prinsip yang ditekankannya dari al-indhär (peringatan), al-tabshìr (pemberi khabar gembira), dan al-irshäd (petunjuk) dan mengupayakan rekonstruksi dan pembaharuan. ${ }^{17}$ Rida turut merujuk kepada karya-karya tafsir yang muktabar dari Tafsì al-Tabarì, kepada Tafsì al-Jalälayn hingga Tafsìr al-Alüsì dan mengambil pandangan moderat yang berpijak kepada idealisme salaf: "setelah guru wafat, aku menggunakan metode penafsiran yang berbeda dengan metode yang telah digunakan guru. Metode tersebut adalah memperluas penjelasan dengan hadith-hadith sahih, menahkikkan sementara kosa kata, kalimat, dan masalah-masalah yang telah menimbulkan perbedaan pendapat di kalangan ulama, memperbanyak ayat-ayat penguat yang dipetik dari berbagai surat, menahkikkan masalah-masalah yang sangat dibutuhkan pemecahannya oleh kaum Muslim masa kini dengan berdasarkan hidayah agama mereka memperkuat argumen-argumen mereka dalam menghadapi musuh-musuh mereka, baik yang berasal dari kalangan kafir maupun bid'ah, atau memecahkan berbagai masalah dengan cara yang dapat menenteramkan hati dan menenangkan batin." 18

Menurut Charles C. Adams, pemikiran Abduh yang kritis terhadap hadith dan sains dizahirkan oleh Rida dalam Tafsir al-Manär yang menarik beberapa pandangan dan prinsip yang digariskan tentang sunnah dan keautentikannya dan pengaruhnya dalam tafsir yang diketengahkan: "the field in which he has shown particular proficiency is the field of the traditions. The emphasis which the 'Abdub movement places upon the 'genuine' sunnah only, as one of the essential sources of the revised Islam, has made this necessary. In the ability to test the genuineness of the various traditions, be has developed, in Goldziher's opinion, 'a great mastership that reminds one at times of the ancient classics of hadith criticism.' His writings give evidence, also, of familiarity with a number of modern sciences, which he turns skillfully to account in his interpretation and defense of Islam."19

Metode tafsir saintifik yang digariskan dalam Tafsìr al-Manär diperlihatkan dari tafsir surah al-Hijr ayat 22 "dan kami utus angin-angin itu mengawinkan" Abduh mengulas tentang peranan angin dalam mengahwinkan bunga "orang Arab telah tahu mengawinkan pohonpohonan itu dan mereka sendiri pun sudah mempraktikkannya dengan memindahkan bibit bunga jantan kepada bunga yang betina, tetapi sebelum Qur'an turun, seorang pun belum ada di antara bangsa Arab yang mengetahui bahwa anginlah yang mengerjakan demikian. Ahli-ahli

${ }^{16}$ Muhammad Abduh. Tafsir Juz 'Amma, terj. Muhammad Baqir. Pengantar oleh M. Quraish Shihab. (Jakarta: Penerbit Mizan, 1998), vii

${ }^{17}$ Ridā, Rashīd, Tafsìr al-Qur'ān al-Hakim al-mushtahar bi ism Tafsìr al-Manār. Cet. 2. (Kaherah: Dar al-Manar), 1947, 17.

${ }^{18}$ Ridā, Rashīd, Tafsìr al-Qur'ān al-Hakèm al-mushtahar bi ism Tafsìr al-Manār. Cet. 2. (Kaherah: Dar al-Manar, 1947), 16.

${ }^{19}$ Charles C. Adams. Islam and Modernism in Egypt. (New York: Russell \& Russell, 1968), 80. 
tafsir, pun tidak memahamkan ayat ini, tetapi mereka tanggungkan saja atas jalan majazi (tidak haqiqi)." 20

Analisis saintifik yang signifikan juga diperlihatkan dalam surab al-Anbiyä, ayat 30 yang menjabarkan asas saintifik dari ilmu falak, seperti dirumuskan dalam kitab Tafsir al-Qur'anulKarim yang membincangkan ide yang dikemukakan dalam Tafsìr al-Manār: "Apakah tidak diketahui oleh orang kafir itu bahwa langit dan bumi itu tadinya adalah dua benda yang bersatu, maka Kami pisahkan keduanya, dan Kami jadikan segala sesuatu yang hidup itu daripada air, kenapa kamu tidak percaya", "dahulu di mana ada orang yang tahu bahwa langit itu tadinya bersatu dengan bumi, tetapi ilmu falakiyah yang baru sudah dapat memastikan bahwa bumi itu ada satu bintang juga seperti lain-lain bintang yang dikatakan mereka langit. Dahulu di mana ada orang tahu bahwa segala yang hidup itu berasal dari air, tetapi sekarang orang sudah mengerti; bukan air mani yang dimaksud di sini, karena kalau itu dari dahulupun sudah tahu. Tetapi air yang sebenarnya, karena kalau tidak ada air, satu apa juga tidak akan bisa hidup di dunia ini. Menandakan bahwa segala yang ada di muka bumi ini amat berhajat kepada air. Ahli-ahli tubuh manusia zaman sekarang sudah mengatakan: di dalam tubuh manusia lebih banyak air dari pada yang lain." ${ }^{\prime 1}$

Dalam tafsirannya pada surah al-Baqarah, ayat 23-24, Abduh mempertahankan asas saintifik yang mendasari keilmuan falak yang berbeza dengan ilmu nujum "adapun, tentang pengetahuan ahli falak dari hal perjalanan matahari, bulan, gerhana dan lain-lain, itu sama sekali tidak masuk 'ilmu nujum dan tidak sedikit juga masuk bahagian ilmu ghaib."22

Beliau turut membahaskan ketinggian mukjizat al-Qur'an (ijär) dalam tafsirannya pada surah al-Baqarah ayat 23-24, (yang dikaitkan juga dengan pernyataan dalam surah al-Isra ayat 88) yang menjelaskan kebenaran ayat al-Qur'an tentang kelangsungan mukjizatnya sepanjang abad dan zaman, yang tidak dapat ditiru atau dikalahkan dengan kefasihan dan kekuatan ungkapan yang sepertinya "dan jika kamu ragu-ragu tentang Qur'an yang Kami turunkan atas hamba Kami ini, cubalah Kamu perbuat barang satu surat yang seumpamanya dan undanglah tuhan-tuhan kamu selain dari Allah jika sekiranya kamu orang yang benar. Maka jika tidak kamu perbuat dan kamu ta'kan dapat memperbuatnya, maka takutlah kamu akan neraka yang kayu penyalaannya manusia dan batu-batu (berhala) yang sengaja disediakan bagi orang yang kafir," Abduh mengupas, "sebegitu banyak mashaf di atas dunia ini, sehingga tak terhitung banyak jumlahnya dan orang-orang yang menghafaz al-Qur'an di atas dunia ini, ada beriburibu banyaknya, meskipun telah lebih seribu tahun lamanya, belumlah pernah terdengar pada kita ada orang yang sudah bisa memajukan satu surat yang semisal Qur'an karena kalau ada tentulah dengan sebentar saja khabar itu tersiar dalam dunia ini dan boleh jadi menjadi satu fitnah besar yang membawa murtad sebahagian orang Islam dari agamanya." ${ }^{23}$

Seterusnya beliau menerangkan tentang hujah-hujah saintifik dalam al-Qur'an tentang alam dan sumber khazanahnya yang besar, "Sesungguhnya al-Qur'an adalah satu kitab yang banyak sekali mengandung ayat-ayat Allah yang menerangkan segala macam jenis makhluk, seperti tumbuh-tumbuhan, bintang-bintang, manusia, jamadat (zat-zat yang mati), peristiwa langit dan matahari, bulan dan bintang-bintangnya, perihal bumi dengan isi-isinya seperti udara, awan, angin, air, sungai, laut yang mengambil tempat dua pertiga dari muka bumi ini, keadaan barang-barang logam, berita-berita ummat yang hidup di zaman dahulu, serta memberi keterangan apa yang mesti dilakukan supaya segenap ummat dapat tinggal damai,

${ }^{20}$ Abdul Halim Hasan, Zainal Arifin Abbas, Abdul Rahim Haitami. Tafsir al-Qur'anul al-Karim, cet. 8. (Medan: Firma Islamiyah, 1956), 96-97.

${ }^{21}$ Abdul Halim Hasan, Zainal Arifin Abbas, Abdul Rahim Haitami. Tafsir al-Qur'anul al-Karim, cet. 8. (Medan: Firma Islamiyah, 1956), 96-97.

${ }^{22}$ Abdul Halim Hasan, Zainal Arifin Abbas, Abdul Rahim Haitami. Tafsir al-Qur'anul al-Karim, cet. 8. (Medan: Firma Islamiyah, 1956), 94.

${ }^{23}$ Abdul Halim Hasan, Zainal Arifin Abbas, Abdul Rahim Haitami. Tafsir al-Qur'anul al-Karim, cet. 8. (Medan: Firma Islamiyah, 1956), 96 
sama rata dan lain-lainnya. Sekalian keterangan Tuhan itu sekarang sudah berumur lebih 13 $1 / 2$ abad." 24

Tekanan terhadap idealisme sains yang intens yang diangkat dalam Tafsìr al-Manār, menurut Moeslim Abdurrahman, adalah disebabkan pengaruh moden di Mesir dan bagi menangani tentangan sekular yang masif: "karena desakan zamannya, Abduh telah menyumbangkan tafsirnya yang berwatak rasional modern serta saintifik. Tafsir al-Manar telah menjawab tantangan yang kuat dan pengaruh sekuler dengan strategi yang jitu, yakni mengintegrasikan pemikiran positivisme ke dalam tafsir modern. Hasilnya, Al-Manar tidak apriori terhadap kebenaran saintifik dengan agama, atau akal dan wahyu." 25

Menurut Quraish Shihab, uraian Abduh tentang malaikat, dalam Tafsir al-Manār, adalah bersifat saintifik yang difahaminya sebagai " natural power" atau "bisikan nurani manusia." Abduh menekankan bahwa penafsiran al-Qur'an harus dapat difahami dan dicerna oleh akal fikiran. Pemahaman secara metaforis, hanya dikemukakan dalam menangani ayat-ayat kalam dan antropomorfisme. Dalam tafsir surah al-Fìl, 3-4, (Țayran Abäbil, Hijäratan min Sijjil) dengan batu-batu dari tanah, Abduh menakwil bahawa ayat tersebut tidak dapat dipahami oleh akal, jika ditafsirkan sebagaimana pemahaman popular yang bersifat suprarasional. Beliau merinci pengertiannya dengan kefahaman akliah "sejenis lalat atau nyamuk [atau mikrob] yang membawa bakteri-bakteri dan mengakibatkan penyakit cacar dan campak." 26 (Muhammad Abduh, 1998, viii)

\section{Rumusan}

Dalam merumuskan manhaj tafsir al-'ilm yang dilakarkan dalam kitab Tafsìr al-Manār ini, dapat disimpulkan bahawa (1) kitab ini memaparkan ide sains yang substantif (2) Dalam kupasannya tentang ayat-ayat saintifik, Tafsì al-Manär lebih seimbang dan ringkas berbanding kitab-kitab tafsir al-ílm yang lain [seperti Tafsir al-jawäbir] yang membentangkan pandangan sains dan teknologi yang ekstensif (3) kedua-dua penafsir (Abduh dan Rida) ini mempunyai persamaan dalam menggagaskan ide moden dan pembaharuan (ișläh) dan penekanan terhadap kekuatan sains (4) corak yang konsisten dalam kerangka tafsir yang dipakai beraliran al-adabi al-ijtimā́ yang digariskan oleh Abduh dan dilanjutkan oleh Rida.

Fikrah tafsiriyah yang ketara dalam Tafsir al-Manär yang mengetengahkan aspirasi moral dan etika yang mendalam turut disorot oleh J.M.S. Baljon dalam bukunya Modern Muslim Koran Interpretation yang memperlihatkan bahawa Tafsir al-Manār lebih menjurus kepada manhaj tradisional yang menfokuskan kepada idealisme moral dan akhlak, "it turns out that their way of exposition does not deviate considerably from the traditional one. In my opinion the most distinguishing feature of 'Abduh's Koran comments is his apparent desire to give moral lessons whenever the text affords an opportunity." 27 (J.M.S. Baljon, 1968, 5).

Diskusi pembaharuan dan ide saintifik menunjangi pemahaman tafsir yang dibawa. Ia menebarkan gagasan moden dan ide-ide reform yang kritis, dan memperjuangkan transformasi sains dan teknologi yang substantif. Lapangan tafsir digunakan sebagai platform untuk mencetuskan revolusi saintifik berasaskan kefahaman rasional terhadap al-Qur'an. Manhaj saintifik yang dikemukakan ini merupakan pendekatan yang penting dalam tafsir alQur'an di abad moden, dan prinsip yang diilhamkan telah memberi pengaruh kepada karyakarya tafsir yang muktabar di rantau melayu, seperti Tafsir al-Qur'anul-Karim oleh H. Abdul Halim Hassan, Zainal 'Ariffin 'Abbas dan Abdur Rahim Haitami, Tafsir al-Az̧bar oleh Shaykh Abdul Malik bin Abdul Karim Amrullah dan Tafsir al-Qur'an al-Hakim oleh Mustafa Abdul Rahman. Tafsìr al-Manārjuga telah menunjukkan pengaruh yang kritis terhadap Tafsìr al-Jawāhir

${ }^{24}$ Abdul Halim Hasan, Zainal Arifin Abbas, Abdul Rahim Haitami. Tafsir al-Qur'anul al-Karim, cet. 8. (Medan: Firma Islamiyah, 1956).

${ }^{25}$ Moeslim Abdurrahman. Islam Sebagai Kritik. Sosial. (Jakarta: Erlangga, 2003), 106.

${ }^{26}$ Muhammad Abduh. Tafsir Juz 'Amma, terj. Muhammad Baqir. Pengantar oleh M. Quraish Shihab. (Jakarta: Penerbit Mizan, 1998), viii.

27J.M.S. Baljon. Modern Muslim Koran Interpretation (1880-1960) (Leiden: E.J. Brill), 1968, 5. 
[al-Jawähir fì Tafsìr al-Qur'än al-Karim: al-Mushtamil'alà Ajä̀̈b Badäli al-Maknūnät wa Gharäib alAyyàt al-Bāhirab] oleh Shaykh Țanțāwī Jawharī (1862-1940) yang bercorak ilmiah (sains) tulen. Ini dizahirkan oleh Muzaffar Iqbal dalam bukunya The Making of Islamic Science, bahawa (Tafsir al-Jawähir) "ini merupakan salah satu dari tafsir saintifik yang komprehensif yang mana penulisnya terkesan dengan al-Manar." Pengaruh Abduh dan inspirasi perjuangannya yang dibawa oleh Tantawi dalam Tafsir al-jawähir ini turut diperincikan oleh Charles C. Adams dalam bukunya Islam and Modernism in Egypt.

"Dr Hartmann states directly that Shaikh Tantawi was a pupil of Muhammad 'Abduh. The statement is abundantly confirmed by a comparison of the doctrines contained in these works with those of 'Abduh. The chief Qur'an passage to which the author gives a detailed explanation in his first work was Surah ii. 159, on the signs of God in nature, the passage which had led him to the study of natural science; this is one of the main passages upon which 'Abduh relies as a summons to the study of God in nature rather than in dialectic speculation. All the familiar formulae of the "Abduh teaching are present: Islam is a religion of understanding and thought, not of taklid; the study of the sciences, if rightly understood, becomes a service of God; veneration of prophets and saints is to be opposed; exclusive adherence to one school of canon law is the source of rigidity and backwardness in Islam; independent investigation (ijtihäd) is the solution for all the ills of the time." 28 (Charles C. Adams, 1968, 247).

Ia memberi pemahaman alternatif dan menjadi rujukan utama dalam ittijāh al-ílm yang dibawa dalam tafsir moden. Bagaimanapun, terdapat kelemahan teoretikal dalam karya ini seperti dilontarkan oleh Hazem Mouhi Edin dalam kajiannya tentang manhaj pembaharuan yang dibawa oleh Tafsì al-Jawähir dan Tafsì al-Manär yang melibatkan idealisme tafsir yang digagaskan dan sudut praktis dan penerapannya yang sebenar:

"however, on balance, the two exegetes have not succeeded in creating a theoretical method for the interaction between the Qur'an and its interpretation on the one hand and facts of reality and history on the other hand. This has resulted in some shortcomings in the applied aspect of their exegesis" 29 (bagaimanapun, ratanya, keduadua tafsir ini tidak berjaya dalam mencipta metode teoretis dalam interaksi antara alQur'an dan interpretasinya pada satu pihak dan kenyataan sejarah dan realitas pada pihak yang lain. Ini telah mengakibatkan beberapa kekurangan pada aspek aplikasi dalam tafsiran mereka."

\section{Kesimpulan}

Dari perbincangan ringkas tentang metode saintifik yang dijabarkan dalam Tafsir alManär ini, kita telah melihat kekuatan karya ini dalam mengemukakan ide pembaharuan dan saintifik yang signifikan, dan menangani ayat-ayat dan tema ilmiah yang mendasar. Ia termasuk karya tafsir yang paling berpengaruh pada awal abad 20 yang "mempunyai peranan yang tidak kecil dalam pencerahan pemikiran serta penyuluhan agama." 30

Ia melakarkan asas yang penting dari manhaj saintifik yang meraikan konteks masyarakatnya yang bangkrut dan jahil tentang kefahaman agama dan prinsip syariat, seperti diterangkan oleh N. S. Pauzi, dan R. A. Ibrahim: "Antara pentafsir yang sering mengaitkan persekitaran semasa dengan penafsiran ayat al-Quran ialah Rashid Rida. Ketika beliau menafsirkan ayat 188 surah al-Baqarah, [And devour not one another's possessions wrongfully, and neither employ legal artifices with a view to devouring sinfully, and knowingly, anything that by right belongs to others] beliau secara jelas mengaitkan ayat tersebut dengan masyarakat Mesir. Menurut Rashid Rida, masyarakat Mesir pada zamannya tidak mematuhi ajaran yang terkandung dalam

${ }^{28}$ Charles C. Adams, Islam and Modernism in Egypt (New York: Russell \& Russell, 1968), 247.

${ }^{29}$ Hazem Mouhi Edin. "Al-Ișlāḥ al-Siyāsī 'inda Mufassiri al-Qur’ān al-Karīm fĩ al-Niṣf al-Awwal min alQarn al-'Ishrīn: Rashīd Riḍā wa Tanțāwī Jawharī Namūdhajan.” Tesis PhD, Kulliyyah of Islamic Revealed Knowledge and Heritage, IIUM, 2008.

${ }^{30}$ M. Quraish Shihab. Rationalitas Al-Qur'an: Studi Kritis atas Tafsir al-Manar (Ciputat: Lentera Hati, 2006) 
ayat tersebut. Mereka banyak melakukan litigasi, perselisihan dan memfitnah orang lain di hadapan penguasa, demi mendapatkan harta dan wang daripada orang lain." "31

Kitab ini melantarkan asas yang penting tentang kefahaman al-Qur'an yang rasional, dan melakarkan pendekatan yang bersifat moderate, dan memperlihatkan kesejajaran nilai agama dan falsafah sains yang membuktikan kebenaran al-Qur'an. Ia menggariskan manhaj saintifik yang tulen dan rasional yang patut kita kembangkan sebagai sumbangan yang bernilai dari usaha intelektual yang monumental ini dalam tradisi pemikiran dan warisan tafsir di abad moden.

\section{Daftar Pustaka}

A. Athaillah. Rasyid Ridha: Konsep Teologi Rasional dalam Tafsir al-Manar Jakarta: Erlangga, 2006. Abbas, Fadl Hassan. Al-Mufassirun Madarisubum wa Manabijubum. Amman: Dar al-Nafa'is, 2007 Abduh, Muhammad. Al-A'mal al-Kamilab [The Complete Works]. Diedit oleh Muhammad 'Imarah. Beirut: Dar al-Shuruq, 1993.

Abduh, Muhammad. Tafsir Juz 'Amma, terj. Muhammad Baqir. Pengantar oleh M. Quraish Shihab. Jakarta: Penerbit Mizan, 1998.

Abdullah, Ismail, Sayuti Abdul Manas. "Manhaj al-Shaykh Țanțāwī Jawharī fī Tafsīirihi "alJawähir fi Tafsì al-Qur'ān al-Karim," Journal of Islam in Asia, 2 (2011)

Abdullah, Mustaffa. "Sejarah Penulisan Tafsir al-Manar Karya Sayyid Muhammad Rasyid Rida," Jurnal al-Bayan vol. 3 (2005), 55-64.

Abdurrahman, Moeslim. Islam Sebagai Kritik Sosial. Jakarta: Erlangga, 2003.

Adams, Charles C. Islam and Modernism in Egypt. New York: Russell \& Russell, 1968.

al-Dhahabī, Muḥammad Ḥusayn. Al-Tafsir wa'l-Mufassirūn. Cairo: Maktabah Wahbah, 2003.

al-Fadi, Muhammad. Al-Tafsir wa Rijäluh. Kaherah: Majma' al-Buhuth al-Islamiyyah, 1970.

Al-Ghazali, Abu Hamid Muhammad, Ihyyà' Ulüm al-Din, juz 3. Beirut: Dar al-Ma'rifa, t.t..

Al-Rūmī, Fahd 'Abd al-Raḥman, Ittijāhāt al-Tafsìr fì al-Qarn al-Rābi' 'Ashar. Beirut: Mu'assasah al-Risālah, 1986.

Amin, Ahmad. Zu'ama`al-Islah fi al-'Asr al-Hadith. Beirut: Dar al-Kutub al-Ilmiyah, 2005.

Baljon, J.M.S. Modern Muslim Koran Interpretation (1880-1960). Leiden: E.J. Brill, 1968.

Edin, Hazem Mouhi. "Al-Ișlāḥ al-Siyāsī 'inda Mufassiri al-Qur’ān al-Karīm fì al-Niṣf alAwwal min al-Qarn al-'Ishrīn: Rashīd Riḍā wa Țantāwī Jawharī Namūdhajan.” Tesis PhD, Kulliyyah of Islamic Revealed Knowledge and Heritage, IIUM, 2008.

Hasan, Abdul Halim, Zainal Arifin Abbas, Abdul Rahim Haitami. Tafsir al-Qur'anul al-Karim, cet. 8. Medan: Firma Islamiyah, 1956.

Iqbal, Muzaffar. The Making of Islamic Science. Westport, Connecticut: Greenwood Press, 2007. Jawhari, Tantawi. Al-Jawāhir fì Tafsìr al-Qur'àn al-Karim: al-Mushtamil 'alà 'Ajä̀ib Badä'i alMaknūnāt wa Gharäìb al-Ayāt al-Bāhirāt. Beirut: Dar al-Kutub al-'Ilmiyah, 2004.

Jawhari, Thanthawi. Al-Quran dan Ilmu Pengetabuan Moderen, terj. Muhammadiyah Ja'far. Surabaya: al-Ikhlas, 1984.

N. S. Pauzi, R. A. Ibrahim. "Pengaruh Persekitaran Terhadap Penafsiran al-Quran". Proceeding The $3^{\text {rd }}$ World Conference on Islamic Thought and Civilization (WCIT2016), 884-895.

Rida, Muḥammad Rashīd b. 'Alī Rị̣ā b. Muḥammad Shams al-Dīn b. Muḥammad Bahā' alDīn b. Munlā 'Alī Khalīfah al-Qalmūnī al-Husaynī (w. 1354 H). Tafsir al-Manar. Mesir: Al-Hai'ah al-Misriyah al-Ammah li al-Kitab, 1990.

Ridā, Rashīd, Tafsìr al-Qur'ān al-Hakim al-mushtahar bi ism Tafsìr al-Manār. Cet. 2. Kaherah: Dar al-Manar, 1947.

${ }^{31}$ N. S. Pauzi, R. A. Ibrahim. "Pengaruh Persekitaran Terhadap Penafsiran al-Quran”. Proceeding The $3^{\text {rd }}$ World Conference on Islamic Thought and Civilization (WCIT2016), 884-895. 
Shihab, M. Quraish. Rationalitas Al-Qur'an: Studi Kritis atas Tafsir al-Manar. Ciputat: Lentera Hati, 2006.

Syaḥātah, 'Abdullāh Maḥmūd. Manhaj al-Imām Muhammad 'Abduh fì Tafsìr al-Qur'ān al-Karìm. Kaherah: al-Majlis al-A'lā li Ri'āyah al-Funūn wa al-Adab wa al-'Ulūm al-Islāmiyyah, t.t.

Toure, Abdoul Karim. Athar al-Zaman cAla Tafsir al-Quran al-Karim Dirasah Muqaranah Bayn Jamic al-Bayan li al-Tabari wa Tafsir al-Manar li Mubammad Rashid Rida. Nilai: Penerbit Universiti Sains Islam Malaysia, 2009.

Yunus, H. Mahmud. Tafsir Quran Karim. Kuala Lumpur: Pustaka al-Azhar, 1987. 